\title{
Konseling Keluarga untuk Meningkatkan Ketahanan Keluarga
}

\author{
Ulfiah \\ Fakultas Psikologi, Universitas Islam Negeri Sunan Gunung Djati Bandung, Indonesia \\ e-mail: ulfiah@uinsgd.ac.id
}

\begin{abstract}
The background of this study is based on the significance of family counseling to increase family resilience. This counseling is needed to help families in dealing with complex family problems and involves many factors. The purpose of this study is to review the literatures on family counseling approach in increasing family resilience. This study uses a systematic literature review (SLR) approach from various articles that discuss family counseling, family resilience, and household problems. The author used 3 selection criteria for the literature study: periodization, keywords, and limitation. The results show that the family and family resilience must be seen as a system that has various influencing factors. The important role of family counseling is to help families in dealing with crisis situations, find the right solution, bring out the best potential, and develop the ability to work together.
\end{abstract}

Keywords: counseling, family, family resilience, household problems

\begin{abstract}
Abstrak
Penelitian ini dilatarbelakangi oleh signifikansi konseling keluarga untuk meningkatkan ketahanan keluarga. Konseling ini diperlukan untuk membantu keluarga dalam menghadapi persoalan keluarga yang kompleks dan melibatkan banyak faktor. Penelitian ini bertujuan untuk mengkaji dan melakukan review mengenai pendekatan konseling keluarga dalam meningkatkan ketahanan keluarga. Penelitian ini merupakan pendekatan studi literatur sistematik dari berbagai artikel yang membahas konseling keluarga, ketahanan keluarga, dan problematika rumah tangga. Digunakan tiga kriteria seleksi untuk studi tersebut, yakni: periodisasi, kata kunci, dan limitasi. Hasil analisis literatur sistematik yang ada menunjukkan bahwa keluarga dan ketahanan keluarga harus dilihat sebagai suatu sistem yang memiliki berbagai faktor yang memengaruhinya. Peran penting konseling adalah untuk membantu keluarga dalam menghadapi situasi-situasi krisis, menemukan solusi yang tepat, mengeluarkan potensi terbaik, dan mengembangkan kemampuan bekerjasama dalam keluarga.
\end{abstract}

Kata Kunci: konseling, keluarga, ketahanan keluarga, permasalahan keluarga

\section{Pendahuluan}

Keluarga pada dasarnya adalah sebuah perkumpulan yang berusaha menciptakan keintiman dalam bentuk perilaku sehingga muncul suatu perasaan memiliki (rasa identitas), berupa ikatan emosi, pengalaman mendasar, ataupun cita-cita bersama. Pengertian seperti ini menunjukkan bahwa keluarga harus bisa melaksanakan fungsinya dengan baik untuk mencegah berbagai persoalan yang seringkali timbul dalam keluarga (Ulfiah, 2016). Keluarga inti umumnya terdiri dari ayah, ibu, dan anakanak, maupun saudara dalam satu rumah yang terdiri dari struktur inti dan batih. Semua unsur keluarga tersebut memiliki fungsi yang menunjang keberadaan dan kebahagiaan satu sama lain dalam keluarga.

Sebuah keluarga dapat disebut sebagai keluarga yang bahagia dan sehat, ketika keluarga tersebut bisa memenuhi beberapa kriteria penting, terutama yang berhubungan dengan perkembangan anak, kehidupan beragama, memiliki waktu berkumpul bersama, ada suatu pola konsumsi yang bisa dirasakan bersama dan saling menghargai (Yanti, 2020). Keluarga merupakan ruang pertama bagi seseorang untuk mendapatkan pendidikan dan 
pembelajaran. Dalam istilah lain, keluarga adalah sekolah pertama untuk pembentukan karakter dan perkembangan psikologis seseorang (Ennis \& Bunting, 2013).

Terlepas dari adanya perbedaan struktur tertentu dari keluarga pada setiap tradisi di dalam masyarakat, keluarga menjadi lingkungan awal bagi setiap orang untuk berkembang. Keluarga dianggap sebagai lingkungan pendidikan utama dan paling awal yang akan menentukan masa depan seseorang. Seorang anak yang mendapatkan pendidikan awal yang baik di lingkungan keluarganya, akan mampu mengembangkan keterampilan sosial, emosional, dan fisik mereka dengan baik (Rashid dkk., 2020). Kekuatan dan ketahanan keluarga, dalam hal ini diibaratkan sebagai sebuah fondasi bagi seseorang dimana fungsi keluarga bisa menjaga anggotanya dari berbagai pengaruh negatif sehingga dengan hal itu kehidupan sosial setiap anggota bisa lebih terjaga (Marie \& McClanahan, 2012).

Hal ini pula yang membuat keluarga, terutama setiap subjek yang ada di dalamnya, harus bisa memiliki ketahanan sebagai modal utama untuk pendidikan anak di dalam keluarga. Lalu, seperti ditekankan sebelumnya, pendidikan di lingkungan keluarga ini sangatlah penting bagi anak dimana orang tua dianggap sebagai guru sekaligus sekolah untuk anakanak mereka. Orang tua yang bisa menyiapkan lingkungan pendidikan awal yang baik bagi anak-anak mereka memiliki kecenderungan untuk terus membangun keluarga sebagai lingkungan pendidikan bagi anak ketika beranjak remaja (Lehrl dkk., 2020). Alasan ini pula yang membuat keluarga dan khususnya orang tua sebagai subjek utama dalam keluarga, dipandang sebagai pendidik yang akan mengarahkan anak untuk membuka potensi dirinya. Keberhasilan pendidikan anak, atau pembentukan individu yang kuat dan masyarakat yang baik, pada akhirnya akan banyak bergantung pada keberadaan keluarga yang kuat pula. Keluarga dengan ketahanan yang baik, akan menjadi pilar dalam membentuk individu yang baik demi perwujudan masyarakat yang baik pula.

Meski demikian, keluarga dengan ketahanan yang baik, atau rumah tangga yang harmonis, bukan berarti keluarga tanpa konflik dan masalah. Keluarga dengan ketahanan yang baik justru merupakan keluarga yang diuji dengan berbagai masalah, namun sanggup bertahan dan menemukan jawaban atas masalah tersebut (Walsh, 2016). Berbagai masalah yang umum terjadi dalam rumah tangga sendiri, yang seringkali muncul pada berbagai literatur tentang ketahanan keluarga, diantaranya adalah perceraian, poligami dan perselingkuhan, kekerasan dalam rumah tangga, permusuhan antar saudara, hingga bentuk-bentuk kenakalan tertentu pada anak ataupun orang dewasa (Kolak dkk., 2018). Semua itu menjadi sumber untuk situasi-situasi krisis dalam keluarga yang berdampak pada berbagai penyakit mental serta tekanan psikologis pada anggota keluarga, khususnya anak (Ryan dkk., 2017; D'Onofrio \& Emery, 2019).

Keterampilan atau kemampuan keluarga dalam menangani situasi-situasi krisis dan berbagai problematika yang dihadapi dalam rumah tangga inilah yang nantinya akan menjadi sumber ketahanan dalam keluarga. Kemampuan masingmasing keluarga dalam menghadapi berbagai masalah tersebut, akan membentuk seberapa besar daya tahan keluarga dalam merespon persoalan yang ada di masa depan. Dengan demikian, ketahanan keluarga adalah suatu proses aktif yang dijalani keluarga untuk menghadapi banyaknya masalah yang datang, untuk memenuhi kebutuhan serta pertumbuhan (Walsh, 2016). Kemampuan yang dimiliki itu tentunya bersumber dari pengalaman masa lalu yang pernah dirasakan oleh setiap anggota keluarga. Hal ini menjadi penting untuk mengajarkan pada anak-anak bagaimana menghadapi permasalahan sejak dini agar mereka bisa 
menyelesaikannya segera dan tidak berdampak panjang hingga masa dewasa. Pentingnya ketahanan keluarga, bukan hanya untuk mempertahankan kehidupan berumah tangga, melainkan juga utamanya untuk menentukan masa depan anak. Secara teoretis, pentingnya ketahanan keluarga ini adalah karena ketahanan tersebut akan meningkatkan kemampuan anggota keluarga dalam menyelesaikan konflik, meningkatkan kepedulian di antara anggota keluarga, menjauhkan keluarga dari situasi yang maladaptif, menjaga stabilitas dan ketahanan emosi anggota keluarga, serta yang lebih utama adalah mewujudkan kesejahteraan keluarga itu sendiri (Nemeth \& Olivier, 2017).

Secara lebih khusus, dalam hal penanganan problematika rumah tangga atau konflik dalam kehidupan berkeluarga akan memengaruhi ketahanan keluarga itu sendiri, terdapat peran penting dari konseling keluarga untuk tidak saja membantu keluarga dalam menyelesaikan berbagai persoalan yang dihadapi, melainkan juga membantu keluarga dalam meningkatkan ketahanan dan kesejahteraannya. Dalam riset sederhana ini, penulis akan menyoroti beberapa poin penting yang menjadi inti bahasan para ahli dalam beberapa literatur terkait peran konseling dalam ketahanan keluarga tersebut, diantaranya: problematika komunikasi sebagai sumber konflik keluarga, konsep dan penerapan konseling dalam keluarga, dan konseling untuk ketahanan keluarga.

Konseling keluarga ini dianggap perlu untuk meningkatkan ketahanan keluarga, terutama ketika persoalan keluarga yang didapati hari ini semakin kompleks dan melibatkan banyak faktor. Persoalan keluarga berarti persoalan individu anggota keluarga yang membawa dampak pada keluarga sehingga menjadi persoalan bersama sebagai kolektivitas keluarga. Dalam hal ini, konseling keluarga tersebut, sebagaimana hasil penelusuran penulis atas berbagai literatur tentang ketahanan keluarga, memiliki beragam teknik, metode, dan model yang bisa dipilih dan digunakan para terapis agar selaras dengan persoalan yang dihadapi.

Apa yang menghubungkan konseling keluarga dengan ketahanan keluarga sendiri adalah peran konseling untuk membantu setiap anggota keluarga sebagai satu kesatuan kolektif dari berbagai individu yang berbeda pilihan dan pemahaman dalam menghadapi persoalan, yang membuat setiap anggota keluarga memiliki daya tahan lebih tinggi ke depannya. Ketahanan keluarga adalah hasil dari benturan keluarga dengan persoalan, dan konseling keluarga adalah salah satu alternatif penting bagi keluarga untuk menghadapi persoalanpersoalan keluarga tersebut. Dengan demikian, penelitian ini bertujuan untuk mengkaji dan melakukan review mengenai pendekatan konseling keluarga dalam meningkatkan ketahanan keluarga

\section{Metode Penelitian}

Penelitian ini menggunakan pendekatan studi literatur sistematik atau systematic literature review (SLR) yang bersumber dari berbagai literatur mengenai konseling ketahanan keluarga dalam menangani problematika rumah tangga. Tinjauan kepustakaan atau literature review sendiri adalah studi objektif melalui ringkasan dan analisis kritis terhadap literatur riset ataupun non-riset terkait topik tertentu yang dipelajari (Hart, 1998). Tujuan utama dari penggunaan pendekatan ini adalah untuk mendapatkan gambaran tentang teori dan konsep tentang konseling ketahanan keluarga yang paling sering muncul ke permukaan. Literatur tentang konseling ketahanan keluarga menjadi sumber utama dalam penulisan artikel ini, yang diambil dari berbagai sumber data (multiple databases), yang mencakup buku, publikasi media, indeks kumulatif tentang ketahanan keluarga, konseling keluarga, dan problematika dalam kehidupan berkeluarga. 


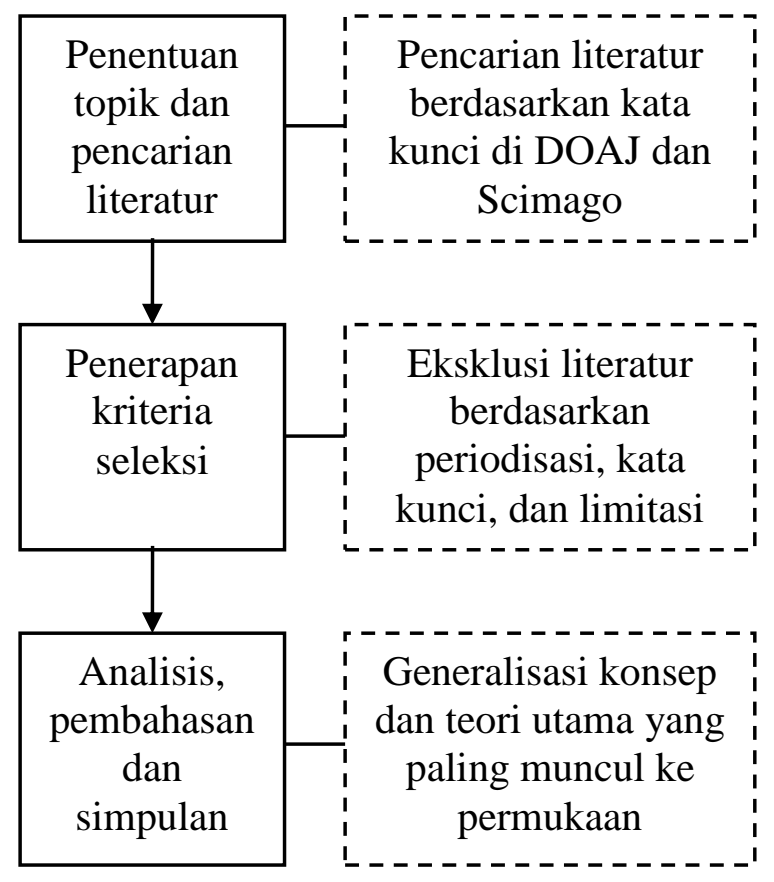

Gambar 1. Proses studi literatur sistematik

Kriteria seleksi untuk memilah hasil pencarian tersebut adalah: (1) Periodisasi, literatur tentang konseling ketahanan keluarga difokuskan pada literatur yang dipublikasi mulai dari tahun 2011 hingga 2021; (2) Kata kunci, literatur diseleksi berdasarkan kata kunci untuk proses eksklusinya, yakni konseling ketahanan keluarga dan problematika rumah tangga; dan (3) Limitasi, literatur dan materi utama yang dirujuk adalah materi-materi yang secara general paling tampil ke permukaan, terutama dari jurnal yang terindeks di DOAJ dan Scimago.

Dalam praktiknya, penulis mengumpulkan buku-buku atau artikel jurnal yang berhubungan dengan topik pembahasan, kemudian memilah bahasan yang relevan dari masing-masing literatur tersebut. Melalui data-data tentang konseling ketahanan keluarga dari berbagai literatur yang dikumpulkan tersebut, penulis kemudian menganalisis berbagai akar permasalahan ketahanan keluarga dan konseling yang diperlukan sehingga dapat dijadikan kesimpulan yang komprehensif. Dalam hal ini, penulis merumuskan lima dimensi bahasan sebagai batasan kajian, yakni: (1) konsep dasar keluarga dan ketahanan keluarga; (2) problematika dalam rumah tangga; (3) konsep dasar konseling keluarga; (4) penerapan konseling keluarga; dan (5) konseling untuk ketahanan keluarga.

Namun demikian, mengingat artikel terkait kata kunci yang diterapkan menghasilkan jumlah publikasi yang cukup banyak, yaitu 413 artikel, yang mencakup review buku, riset akademis, editorial, dan proceedings. Penulis kemudian melakukan proses eksklusi berdasarkan limitasi konsep dan spesifikasi tema bahasan, hingga tersisa 28 artikel utama. Penulis kemudian melakukan analisis lebih mendalam berdasarkan 5 (lima) dimensi bahasan sebelumnya.

\section{Hasil Penelitian dan Pembahasan}

Keluarga, problematika keluarga, konseling keluarga, dan ketahanan keluarga merupakan konsep-konsep yang saling terkait satu sama lain. Keluarga merupakan unit kecil yang dihuni oleh setiap orang dan menjadi tempat di mana orang membawa segenap persoalan hidupnya. Hal inilah yang membuat konseling keluarga dibutuhkan untuk mengatasi berbagai persoalan tersebut. Konseling keluarga ini pada gilirannya diharapkan bisa membantu keluarga dalam menghadapi berbagai tekanan dan situasi-situasi krisis, yang menjadi sumber dan modalitas utama untuk memperkuat ketahanan keluarga. Karena itu, dalam penelitian ini, konsep-konsep tersebut dihubungkan dalam alur seperti tampak pada gambar 2 .

\section{Konsep Dasar Konseling Keluarga}

\section{Pengertian Konseling Keluarga}

Apakah konseling keluarga sebenarnya?. Dalam beberapa literatur, keluarga adalah metode yang dirancang dan difokuskan pada keluarga dalam usaha untuk membantu memecahkan permasalahan klien dalam keluarga. 


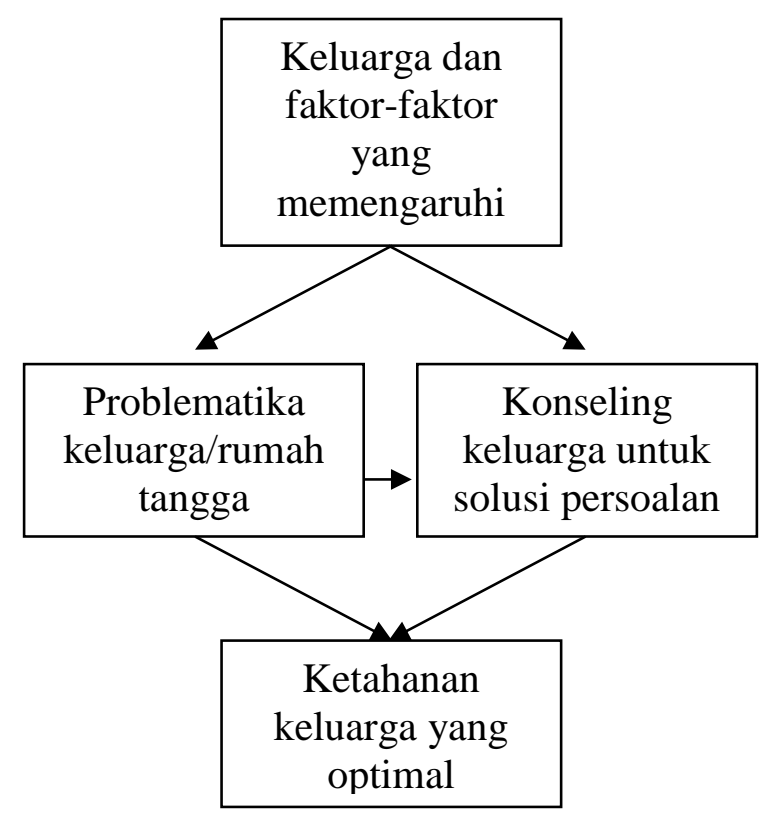

Gambar 2. Kerangka berpikir penelitian

Masalah yang muncul dalam konseling keluarga ini pada dasarnya bersifat pribadi karena dialami oleh klien itu sendiri. Akan tetapi, konselor menganggap permasalahan yang dialami klien tidak semata disebabkan oleh klien sendiri, melainkan dipengaruhi oleh sistem yang terdapat dalam keluarga klien. Sehingga keluarga diharapkan ikut serta dalam menggali dan menyelesaikan masalah klien (Lubis, 2011). Konseling keluarga merupakan salah satu aplikasi dari perkembangan konseling. Capuzzi mengatakan perkembangan konseling keluarga di Amerika terjadi sejak tahun 1950-an yang dikembangkan oleh beberapa ahli antara lain: Nathan Ackerman, Theodore Lidz, Lyman Wynne, Murray Bowen, dan Carl Whitaken. Tokoh-tokoh tersebut pada umumnya adalah para psikiater yang menganut paham psikoanalisis untuk mengembangkan konseling keluarga dan perkawinan (Lubis, 2011).

Apabila dilihat lebih jauh, dalam konseling keluarga terdapat pemahaman bahwa keterlibatan seluruh anggota keluarga sangat dibutuhkan dalam konseling. Adanya dukungan keluarga ini bukan saja bisa mendatangkan solusi yang diharapkan, tapi juga dapat menanamkan rasa tanggung jawab setiap anggota keluarga untuk ikut terlibat dalam memecahkan masalah bersama. Dengan kata lain, klien konseling tidak lagi memecahkan masalahnya sendiri melainkan memperoleh dukungan dan kerjasama yang baik dari pihak keluarganya. Pendekatan yang melibatkan seluruh anggota keluarga ini lazim dilakukan pada Multi-Systemic Therapy (MST), Cognitive Behaviour Therapy (CBT), Structural Family Therapy (SFT), Experiential Family Therapy (EFT), Solution Focused Brief Therapy (SFBT), ataupun Narrative Therapy (Evans dkk., 2012).

Konseling keluarga, dengan demikian adalah upaya bantuan yang diberikan kepada individu anggota keluarga melalui sistem keluarga, terutama melalui pembenahan komunikasi keluarga, agar potensi semua anggota keluarga dapat berkembang seoptimal mungkin. Lalu pada gilirannya masalah yang ada juga dapat diatasi atas dasar kemauan membantu dari semua anggota keluarga berdasarkan kerelaan dan kecintaan terhadap keluarga. Dalam hal ini, berbagai faktor keluarga, baik yang positif maupun yang negatif, seperti kohesi keluarga, konflik keluarga, pola pengasuhan, kondisi lingkungan, dan lainnya, dapat berdampak pada perkembangan anggota keluarga itu sendiri (Kelchner dkk., 2020). Kondisi seperti inilah yang membuat konseling seringkali dirancang sebagai metode khusus yang difokuskan pada keluarga sebagai usaha para terapis untuk membantu memecahkan masalah perilaku klien. Dengan demikian konseling keluarga merupkan proses bantuan yang diberikan kepada individu anggota keluarga dalam memecahkan masalah keluarga yang dihadapinya (Rahayu, 2017; Evans dkk., 2012).

Konseling keluarga memandang keluarga sebagai kelompok tunggal yang tidak dapat dipisahkan sehingga diperlukan sebagai satu kesatuan. Maksudnya adalah, apabila salah satu anggota keluarga memiliki masalah, maka hal itu dianggap 
sebagai simptom dari sakitnya keluarga. Hal ini disebabkan kondisi emosi salah satu anggota keluarga yang memiliki masalah, memiliki potensi untuk memengaruhi kondisi emosi anggota keluarga lainnya. Anggota keluarga yang mengembangkan simptom ini disebut sebagai "identified patient" yang merupakan product dan kontributor dari gangguan interpersonal keluarga. Karena itu pula, konseling keluarga ini dapat dilihat sebagai suatu proses interaktif yang berupaya membantu keluarga memperoleh kondisi homeostatis (kemampuan mempertahankan keluarga dalam keadaan seimbang) sehingga anggota keluarga dapat merasa nyaman (Lubis, 2011).

Konseling keluarga ini sangat penting untuk dilakukan tidak saja pada keluarga yang bermasalah, tapi juga pada keluarga yang tanpa masalah sekalipun. Sebab keluarga yang tampak harmonis, bisa saja sebenarnya menyembunyikan persoalan tertentu yang berpotensi meledak suatu waktu. Konseling ini bermanfaat untuk meningkatkan ketahanan keluarga menjadi lebih baik, khususnya pada situasi di mana terdapat reintegrasi maladaptif dalam keluarga. Kondisi reintegrasi maladaptif ini misalnya bisa ditemukan pada keluarga yang saling terhubung satu sama lain, namun ada anggota keluarga yang bermasalah dengan yang lainnya. Misalnya salah satu anggota keluarga merasa benar sendiri, tidak bisa membuka diri terhadap sudut pandang anggota keluarga lainnya.

Melalui berbagai pendekatan dalam konseling keluarga, bisa mencegah kondisikondisi atau hal-hal yang bisa menjadi persoalan dalam keluarga, atau menemukan solusi atas permasalahan yang dihadapi dalam keluarga. Ketahanan keluarga dan konseling keluarga dianggap sangat penting bagi keluarga yang ingin mencapai derajat kesejahteraan tertentu, baik secara materi, mental-psikologis, komunikasi, ataupun spiritual. Karena itu pula, dalam beberapa literatur seperti disebutkan sebelumnya, terdapat tiga kondisi yang menjadi anteseden ketahanan keluarga, yaitu: (1) konflik atau perasaan ketidakseimbangan dalam keluarga; (2) spiritualitas atau nilainilai dan sistem kepercayaan yang ada dalam keluarga; dan (3) tekad kuat keluarga untuk mengatasi persoalan atau kesulitan yang dihadapi (Oh \& Chang, 2014).

Konflik, persoalan, krisis, ketidakseimbangan, dan kerapuhan tertentu yang dirasakan dan disadari oleh anggota keluarga, tidak harus dilihat sebagai hal yang negatif. Hal-hal tersebut justru bisa menjadi peluang untuk meningkatkan ketahanan keluarga. Bagaimanapun, ketahanan hanya akan teruji dengan adanya masalah yang dihadapi. Karena itu, dalam berbagai literatur tentang ketahanan keluarga ini, konsekuensi akhir dari ketahanan keluarga setelah melalui situasi krisis adalah penerimaan atas situasi, perubahan perspektif dalam memandang hidup, peningkatan kualitas hubungan, penguatan ketahanan, dan peningkatan kesehatan dan kesejahteraan keluarga (Oh \& Chang, 2014). Konseling keluarga yang dijalani, dengan demikian, tidak sebatas membantu orang dalam mengatasi persoalan yang dihadapinya, melainkan juga mendapatkan konsekuensikonsekuensi ketahanan keluarga itu sendiri, yakni kesejahteraan secara personal, relasional, hingga spiritual.

Lebih lanjut, dalam berbagai literatur terkait ketahanan keluarga sendiri, kesejahteraan keluarga ini nantinya dapat diukur dengan dua cara, yaitu kesejahteraan objektif dan kesejahteraan subjektif. Sedangkan lingkupnya dapat dibagi menjadi kesejahteraan fisik, kesejahteraan sosial, dan kesejahteraan psikologis. Apabila keluarga telah memiliki nilai, tujuan yang jelas, dan mampu mengelola sumber daya yang dimiliki dengan optimal maka pada akhirnya akan mencapai kesejahteraan secara fisik, yaitu telah mampu memenuhi kebutuhan dasar (pangan dan papan), sosial (memiliki hubungan yang baik dan sehat dengan anggota keluarga maupun masyarakat 
secara luas), dan psikologis (memiliki kepuasan terhadap pencapaian kehidupannya) (Ulfiah \& Hannah, 2018).

Kesejahteraan keluarga, sebagai kondisi akhir yang ingin didapatkan dari konseling dan upaya meningkatkan ketahanan keluarga, dengan demikian dapat dinilai berdasarkan dua hal, yakni: Pertama, kesejahteraan objektif, di mana kesejahteraan diukur dari tingkat pemenuhan kebutuhan dasar dan perkembangan secara objektif, atau mengacu kepada standar normatif dan ideal; serta Kedua, kesejahteraan subjektif, yang merupakan ukuran kepuasan terhadap tingkat pemenuhan kesejahteraan yang ditunjukkan secara objektif dalam keluarga (Ulfiah \& Hannah, 2018).

\section{Konsep Dasar Keluarga dan Ketahanan Keluarga}

Keluarga merupakan arena utama dan pertama untuk melakukan interaksi sosial dan mengenal perilaku-perilaku orang lain. Keluarga juga merupakan tonggak awal dalam pengenalan budaya-budaya masyarakat dalam mana anggota keluarga belajar tentang pribadi dan sifat orang lain di luar dirinya (Ulfiah, 2016).

Dalam hal ini, terdapat definisi keluarga dari Murdock yang menurut penulis memuat pengertian yang paling komprehensif, yakni kelompok sosial yang memiliki karakteristik tinggal bersama, terdapat kerja sama ekonomi, dan terjadi proses reproduksi (Ulfiah, 2016). Mudrock juga menambahkan terdapat tiga tipe keluarga yaitu keluarga inti, keluarga poligami, dan keluarga batih. Keluarga inti merupakan keluarga yang di dalamnya hanya terdapat tiga posisi sosial, yaitu suami atau ayah, istri atau ibu, dan anak sibling. Struktur keluarga demikian menjadikan keluarga sebagai orientasi bagi anak, yaitu keluarga tempat dilahirkan. Sedangkan keluarga batih adalah keluarga yang di dalamnya menyertakan posisi lain selain ketiga posisi di atas. Bentuk pertama keluarga batih yang banyak ditemui adalah keluarga bercabang. Keluarga bercabang terjadi manakala terdapat seorang anak dan anak yang bersangkutan sudah menikah, namun masih tinggal dalam rumah orang tuanya (Ulfiah, 2016).

Istilah ketahanan sendiri, tidak memiliki pengertian dan atau definisi yang baku. Terdapat berbagai penjelasan dari banyak kalangan ahli dalam bidang ini, yang beragam dan memiliki perbedaan batasan satu sama lain. Meski demikian, dalam perbedaan dan ragam penjelasan tersebut, terdapat banyak pandangan tentang resiliensi yang memasukkan metafora ketahanan sebagai kemampuan untuk beradaptasi dalam berbagai situasi dan persoalan hidup. Selain itu, hampir semua definisi ketahanan pada umumnya melibatkan kemampuan untuk menghadapi tantangan dan dengan cara tertentu seseorang bisa menjadi lebih kuat dalam menjalani hidup baik secara personal ataupun bersama-sama (Walsh, 2016).

Dalam beberapa literatur tentang ketahanan keluarga ini, terdapat beberapa karakteristik tentang ketahanan, yaitu: 1) Ketahanan adalah hasil dari berbagai riset terkait tekanan, kemampuan coping, dan adaptasi seseorang/ komunitas terhadap situasi-situasi krisis (Walsh, 2016); 2) Ketahanan adalah konstalasi karakteristikkarakteristik yang memungkinkan seseorang untuk beradaptasi dengan lingkungan, krisis, dan situasi-situasi hidup tertentu (Froutan dkk., 2017); 3) Ketahanan adalah hasil dari proses dan kemampuan diri untuk menghadapi penyakit dan dikembangkan ke dalam studi yang lebih luas (Chew \& Haase, 2016); 4) Ketahanan bisa dihubungkan dengan berbagai ukuran terkait kesehatan mental (Komachi \& Kamibeppu, 2018); dan 5) Ketahanan adalah konstruk yang memayungi berbagai konsep positif yang menunjukkan daya tahan, seperti adaptasi, regenerativitas, koherensi, mekanisme coping, dan perjuangan (Gloria \& Steinhardt, 2016; Roberts dkk., 2017). 


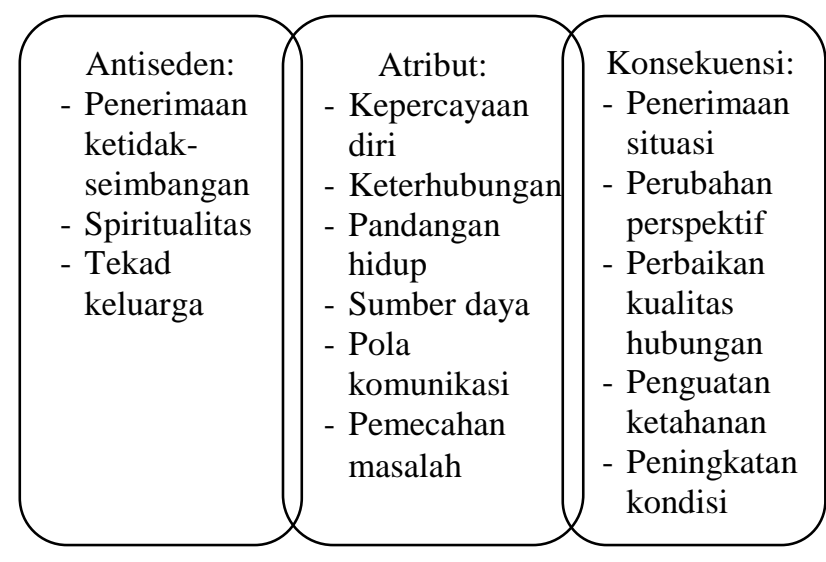

Gambar 3. Anteseden, atribut, dan konsekuensi ketahanan keluarga

Ketahanan keluarga merupakan konsep yang kompleks. Karena itu, para ahli pada umumnya lebih memandang ketahanan ini sebagai suatu proses, bukan semata atribut konstitusional yang tetap, yang dipengaruhi oleh berbagai kondisi keseharian yang ditemui dalam pengalaman hidup bersama sebagai seorang individu atau dalam sebuah komunitas sosial tertentu seperti keluarga. Berdasarkan pandangan seperti ini pula, ketahanan kemudian dapat dikonsepsikan sebagai mekanisme protektif yang memodifikasi respons individu terhadap berbagai situasi yang berisiko dan berlaku pada titik kritis dalam kehidupan seseorang.

Hasil riset Oh dan Chang (2014) sebagaimana disajikan pada gambar 3, menunjukkan bahwa setidaknya ada 3 anteseden untuk ketahanan keluarga, 6 atribut dasar ketahanan keluarga, dan 5 konsekuensi dari ketahanan keluarga yang paling banyak muncul dalam literatur tentang ketahanan keluarga ini, yaitu: 1) Anteseden ketahanan keluarga, yang mencakup: penerimaan atas kondisi ketidakseimbangan (krisis), spiritualitas, tekad keluarga untuk mengatasi persoalan; 2) Atribut ketahanan keluarga, yang mencakup: kepercayaan diri kolektif, keterhubungan, pandangan hidup positif, keterpenuhan sumber daya, pola komunikasi terbuka, pemecahan masalah secara kolaboratif; dan 3) Konsekuensi ketahanan keluarga, yang mencakup: penerimaan atas situasi, perubahan perspektif hidup, perbaikan kualitas hubungan, penguatan properti ketahanan, dan peningkatan kondisi kesehatan (Oh \& Chang, 2014).

\section{Problematika dalam Rumah Tangga}

Berdasarkan paparan sebelumnya, suatu keluarga dikatakan memiliki ketahanan apabila keluarga dapat berperan secara optimal dalam mewujudkan seluruh potensi anggotanya. Ketahanan keluarga, dengan demikian, dapat diketahui dengan mencermati fungsi keluarga. Apabila sebuah keluarga mampu secara optimal melaksanakan fungsinya, maka keluarga tersebut dapat dikatakan memiliki ketahanan. Sebaliknya, apabila keluarga tidak mampu menjalankan fungsinya secara optimal, maka keluarga tersebut akan kurang memiliki ketahanan.

Studi yang ada terkait ketahanan keluarga menunjukkan bahwa ketahanan muncul dan dipengaruhi oleh faktor-faktor yang mencakup faktor ekonomi, sosial, dan manusia (Taylor \& Distelberg, 2016; Yang dkk., 2021). Faktor ekonomi mencakup kemampuan keluarga dalam memenuhi kebutuhan, menabung, berlibur, menjamin masa depan, dan lainnya. Faktor sosial mencakup relasi dengan komunitas, penghargaan dan keterbukaan terhadap sesama, penilaian masyarakat, kondisi sosio-kultural yang melingkupi, dan lainnya. Sedangkan faktor manusia melibatkan perasaan emosional, komunikasi, spiritualitas, kebersamaan, dan lainnya.

Dari berbagai faktor yang memengaruhi ketahanan keluarga tersebut, salah satu faktor terbesar yang seringkali menjadi sumber persoalan dalam kehidupan keluarga atau rumah tangga adalah faktor komunikasi. Komunikasi sendiri adalah aktivitas yang pasti terjadi dalam kehidupan berkeluarga, baik itu verbal maupun nonverbal. Dapat dibayangkan jika dalam keluarga minim komunikasi maka kehidupan keluarga akan sepi dari kegiatan bercengkerama, berbicara, berdialog, 
bertukar pikiran, dan lain sebagainya (Ulfiah, 2016). Dalam konteks keluarga, komunikasi merupakan suatu proses simbolik, proses transaksional, dan proses dalam menciptakan dan berbagi makna kehidupan yang bisa membantu orang tua dalam membentuk perkembangan emosi dan perilaku anak. Karena itu, ketahanan keluarga dan komunikasi keluarga adalah dua konsep yang tidak dapat dipisahkan (Theiss, 2018).

Mossholder mengatakan bahwa berkomunikasi berarti mentransfer pikiran. Komunikasi melibatkan dua sisi, baik suami maupun istri yang merangsang percakapan tetapi bukan suatu alasan (Gerung \& Opit, 2020). Selain itu pengertian komunikasi menurut Wright adalah proses berbagi diri antara suami istri dengan atau tanpa kata-kata, agar pihak lain dapat memahami dan menerima maksudnya. Komunikasi dapat efektif, positif dan membangun, tetapi sebaliknya bisa juga tidak efektif, negatif dan merusak (Doho, 2017). Komunikasi sebagai proses (baik tertulis maupun lisan) berbagi informasi dengan orang lain, dengan cara sedemikian rupa sehingga ia mengerti apa yang sedang dikatakan orang tersebut (Gerung \& Opit, 2020). Apabila komunikasi yang terjadi hanya satu arah, maka komunikasi yang tidak sehat akan terjadi dalam keluarga tersebut. Hal ini pula yang membuat komunikasi efektif dan positif memiliki beberapa aspek yang harus dipenuhi, yakni: kemampuan mendengarkan, keterbukaan diri, bahasa tubuh, ekspresi, kultur dan komunikasi antar gender, kejelasan, dan negosiasi (McCaffrey dkk., 2012).

Komunikasi dua arah atau komunikasi yang melibatkan semua pihak sangat diperlukan di tengah-tengah keluarga. Apabila komunikasi yang terjadi hanya bersifat monolog, bukan dialog, atau bersifat instruksional satu arah, maka akan terjadi pemberontakan diam-diam dalam anggota keluarga. Pihak yang dominan dalam komunikasi akan menjadi pihak yang dibenci, dan pihak yang tidak diberikan kesempatan untuk berbicara akan memendam kemarahan serta berusaha mencari kesempatan menjatuhkan yang lain. Keluarga dengan proses komunikasi yang baik dapat membuat setiap anggota di dalam keluarga tersebut bisa mengetahui pengalaman hidup yang dialami oleh anggota keluarga lainnya. Komunikasi yang baik juga dapat menghindarkan keluarga dari konflik yang seringkali timbul karena kesalahpahaman.

Salah satu kerusakan terbesar di dalam praktik komunikasi adalah dengan membiarkan emosi negatif, seperti rasa marah, terlibat di dalamnya. Ledakan emosi dan kemarahan terpendam dapat mengakibatkan kegagalan dalam berkomunikasi. Dengan kata lain, perasaan yang memendam kemarahan dapat berpengaruh dalam membangun komunikasi terbuka (Gerung \& Opit, 2020). Karena itu pula, dalam proses komunikasi keluarga ini harus ada perhatian pada pesan atau konten yang akan disampaikan, langsung atau tidak langsung pesan itu disampaikan, dan bagaimana penampilan dan keterbukaan yang diberikan oleh seseorang yang melakukan komunikasi (Strotenbeker dkk., 2018). Tanpa perhatian yang baik atas pesan tersebut, maka komunikasi yang efektif akan sulit untuk terbangun, dan pada gilirannya dapat membawa dampak negatif pada ketahanan keluarga serta kesejahteraan keluarga itu sendiri.

Dalam kehidupan berkeluarga, proses komunikasi ini akan menentukan bagaimana sikap keluarga dalam menghadapi konflik dan tekanan atau dalam upaya mereka mencapai derajat kesejahteraan tertentu. Hal ini disebabkan kehidupan suatu keluarga tidak terlepas dari berbagai macam persoalan, baik yang bersumber dari personal suami, isteri, ataupun anak. Karena itu, komunikasi yang baik diperlukan agar persoalan tersebut tidak menjadi sebab keretakan dan berawal dari kesalahan dalam menyikapi dan 
memahami persoalan. Komunikasi yang baik dapat menjadi cara bagi anggota keluarga untuk menyampaikan masalah dan mendapatkan dukungan yang diperlukan untuk menyelesaikan masalah tersebut. Pada gilirannya, hal ini akan memengaruhi keharmonisan dan keutuhan keluarga itu sendiri. Oleh karena itu frekuensi dalam komunikasi dan keterbukaan dari anggota keluarga merupakan kunci komunikasi dalam keluarga (Indrawati, 2015).

Komunikasi sendiri memiliki dua dimensi utama, yakni: dimensi positif berupa keterampilan komunikasi (seperti empati, mendengarkan reflektif, komentar mendukung) yang memungkinkan anggota keluarga untuk berbagi kebutuhan mereka berubah karena mereka berhubungan dengan kohesi, dan kemanapun beradaptasi; serta dimensi negatif (seperti pesan ganda, ganda mengikat, kritik) yang meminimalkan kemampuan untuk berbagai perasaan, sehingga membatasi gerakan dalam dimensi kohesi dan kemampuan beradaptasi. Upaya memahami apakah seseorang merasakan ketenangan dan hubungan yang baik dengan keluarganya, hanya bisa dilakukan dengan mengamati proses komunikasi di antara mereka (Ulfiah, 2016; McCaffrey dkk., 2012).

\section{Penerapan Konseling Keluarga}

\section{Teknik dan Model Terapi}

Penerapan konseling dalam keluarga, seperti halnya upaya pemecahan masalah psikologis tertentu, pada dasarnya bisa menggunakan teknik atau metode yang sesuai dengan masalah yang dihadapi. Namun demikian, menurut Kempler (1968) dalam psikoterapi eksperiensial tidak ada yang disebut dengan teknik konseling, sebab yang ada hanya kemampuan individu itu sendiri. Hal ini memberi kesimpulan bahwa terapis/ konselor eksperiensial sebenarnya lebih banyak menekankan pada kekuatan kuratif (curative) dari kepribadian terapis/ konselor atau pasien itu sendiri. Apabila terapis/ konselor mengharapkan adanya keterbukaan dan kejujuran dari pasiennya, maka para terapis/ konselor harus terlebih dahulu melakukannya. Kemampuan lain yang diharapkan ada dalam diri terapis/ konselor adalah kemampuan berkomunikasi yang baik, memiliki kemampuan bertutur yang jelas, sikap yang sopan, dan jawaban yang tegas sehingga dapat membawa dampak baik pada pasien dalam mengatasi masalahnya (Afdal, 2015).

Dalam berbagai literatur yang dianalisis oleh penulis, pentingnya penguasaan teknik-teknik terapi, seperti joining, use of self, family sculpture, family art therapy, conjoint family therapy, symbolic drawing of family life space, family puppet interviews, role playing, family-life fact chronology, metaphor, menggunakan sentuhan, penggunaan humor, multiple family therapy, communication stances, dan "I" statements, dapat membantu terapis/ konselor dalam memahami masalah yang dihadapi oleh klien/ pasien, sekaligus membantu pasien tersebut menemukan solusi yang tepat atas permasalahan yang dihadapi. Teknik yang baik, tidak saja bisa membuka potensi kreatif dalam diri pasien, melainkan juga dapat memberikan motivasi, dorongan, dan rasa percaya diri pada pasien untuk menghadapi permasalahan secara mandiri (Afdal, 2015). Melalui penggunaan teknik yang baik dan sesuai dengan kebutuhan pasien tersebut, maka terapis/ konselor dapat meningkatkan kemampuan pasien dalam menghadapi situasi-situasi sulit, yang diperlukan untuk membangun ketahanan individu yang berdampak pada ketahanan keluarga pasien itu sendiri.

Adapun bentuk atau model terapi yang lazim digunakan dalam konseling keluarga, seperti disebutkan sebelumnya, dapat dijelaskan sebagai berikut:

Pertama, Experiential Family Therapy (EFT). Model EFT ini adalah model terapi tradisional yang dapat digambarkan sebagai pendekatan psikodinamik. Model ini dikembangkan oleh Satir (1991) dan 
Whitaker (1988). Model ini dalam praktiknya tidak berfokus pada teori tertentu, melainkan pada potensi hubungan yang bisa dikembangkan oleh terapis untuk membantu anggota keluarga dalam membuka wawasan baru terhadap keluarga mereka (Evans dkk., 2012).

Kedua, Structural Family Therapy (SFT). Model SFT dapat dijelaskan sebagai suatu cara berpikir tentang dan beroperasi dalam tiga area, yakni: (1) keluarga; (2) persoalan yang dihadapi; dan (3) proses perubahan. Model ini dikembangkan oleh Salvador Minuchin pada tahun 1960-an. Dalam praktiknya, terapis atau konselor akan membantu keluarga untuk lebih berfokus pada hakikat dan konteks dari persoalan yang dihadapi dibandingkan persoalan itu sendiri. Terapis dalam hal ini akan berusaha mewujudkan perubahan organisasional tertentu dalam keluarga yang tidak berfungsi sebagai tujuan utama mereka (Evans dkk., 2012).

Ketiga, Cognitive Behavior Therapy (CBT). Model CBT pada dasarnya sudah menjadi bagian konvensional dari psikoterapi yang bertujuan untuk mengubah pola pikir dan tindakan individu dengan memodifikasi kesadaran mereka. Model ini sangat ketat dalam menerapkan prinsip dan prosedur ilmiah pada praktiknya. Saat ini, model CBT sudah dikembangkan menjadi beberapa bentuk, yang mencakup Behavioural Couple Therapy (BCT), Integrative Behavioural Couple Therapy (IBCT), dan Behavioural Marriage Therapy (BMT) (Evans dkk., 2012).

Keempat, Multi-Systemic Therapy (MST). Model MST seringkali disebut juga sebagai model terapi keluarga paling jamak, meskipun pada praktiknya terdapat beberapa hal yang membedakannya dengan model intervensi konvensional. MST juga dikenal dengan istilah model terapi berbasis rumah (home-based). Terapi ini biasanya digunakan untuk mengatasi persoalan yang dihadapi keluarga dengan tujuan untuk meningkatkan peluang keluarga yang bersangkutan dalam menemukan solusi-solusi yang dibutuhkan. Model ini menggunakan intervensi holistik dan menekankan pada beberapa sistem kunci di mana individu dan keluarga terlibat, seperti sistem pendidikan dan vokasional, sistem pertemanan dan sosial, serta sistem kekerabatan. Model MST ini dikembangkan sebagai model konseling yang integratif dan efektif, terutama untuk membantu kalangan remaja anggota keluarga yang menunjukkan sikap antisosial (Evans dkk., 2012).

Kelima, Family Problem Solving (FPS). Model FPS didasarkan pada model pemecahan masalah (problem-solving) yang banyak digunakan dalam pelayanan masyarakat. Model ini terus mengalami penyempurnaan, terutama dengan adanya studi oleh para pekerja sosial, psikolog, terapis keluarga, dengan klien dan persoalan yang beragam. Model ini biasanya memiliki 8 (delapan) langkah dalam penerapannya, yakni: klarifikasi peran, survei masalah, ranking masalah, eksplorasi masalah, penetapan tujuan, pengembangan kontrak, pengembangan tugas dan strategi, serta review proses berkelanjutan (Evans dkk., 2012).

Keenam, Solution Focused Brief Therapy (SFBT). Model SFBT dikembangkan oleh Steve de Shazer, Insoo Kim Berg, dan rekan di Brief Family Therapy Center pada tahun 1980-an. Model SFBT ini merupakan model perawatan yang dikembangkan oleh para terapis dengan menerapkan pendekatan pemecahan masalah (problem-solving) dan terapi keluarga sistemik. Beberapa elemen kunci dalam model SFBT ini adalah: identifikasi masalah dan motivasi, pertanyaanpertanyaan ajaib, kemungkinan dan harapan, formasi tujuan, eksepsi dan coping, kepercayaan diri dan kekuatan, serta umpan balik (Evans dkk., 2012).

Ketujuh, Narrative Therapy (NT). Model terapi naratif (NT) ini dikembangkan oleh Michael White dan David Epston. Model NT pada dasarnya adalah suatu set teknik intervensi dari 
kalangan konstruksionis sosial yang dicirikan dengan karakteristik posmodernistik pada terapi keluarga. Model ini dalam praktiknya berupaya untuk membantu orang menguji ulang narasinarasi atau kisah-kisah hidup mereka dalam pembicaraan (Evans dkk., 2012).

\section{Langkah-langkah yang Digunakan dalam Konseling}

Terkait praktik konseling keluarga yang paling umum digunakan, langkahlangkah konseling keluarga meliputi beberapa tahapan berikut: (1) Konselor dan klien mendefinisikan masalah yang dihadapi klien; (2) Klien mengkhususkan perubahan positif yang dikehendaki sebagai hasil konseling; (3) Konselor dan klien mendiskusikan tujuan yang telah ditetapkan mengenai apakah tujuan itu realistis, kemungkinan manfaatnya, atau kemungkinan kerugiannya; (4) Konselor dan klien membuat keputusan apakah melanjutkan konseling dengan menetapkan teknik yang akan dilaksanakan, mempertimbangkan kembali tujuan yang akan dicapai, atau melakukan referal; (5) Menerapkan teknik implementasi, menentukan dan melaksanakan teknik konseling yang digunakan untuk mencapai tingkah laku yang diinginkan yang menjadi tujuan konseling; (6) Evaluasi, melakukan kegiatan penilaian apakah kegiatan konseling yang telah dilaksanakan mengarah dan mencapai hasil sesuai dengan tujuan konseling; dan (7) Feedback atau memberikan dan menganalisis umpan balik untuk memperbaiki dan meningkatkan proses konseling (Rahayu, 2017).

Selain teknik, model, dan langkahlangkah umum yang dijalani dalam proses konseling, konseling keluarga juga memiliki beberapa pendekatan dalam praktiknya. Hal ini tentu saja bertujuan untuk memudahkan konselor dalam memahami permasalahan keluarga dan membantu konselor untuk menangani permasalahan tersebut. Penulis akan menguraikan beberapa pendekatan dalam lingkungan keluarga yang terkenal dan dapat digunakan oleh konselor yang diambil dari berbagai literatur, antara lain:

1) Pendekatan sistem keluarga, 2) Pendekatan model komunikasi, dan 3) Pendekatan struktural.

Pendekatan sistem keluarga diciptakan oleh Murray Bowen, sehingga juga dikenal sebagai Teori Keluarga Bowen. Menurutnya, keluarga merupakan suatu sistem hubungan emosional yang memiliki beberapa konsep kekuatan yang saling berkaitan untuk membentuk fungsi keluarga yaitu: Pertama, Perbedaan diri/ individu. Tingkat perbedaan diri mencakup perbedaan intelektual dan emosional anggota keluarga. Mereka yang tidak dapat menyelaraskan sisi intelektual dan emosionalnya dengan baik, cenderung mudah emosi dan merasa tidak berguna. Sehubungan dengan perbedaan diri ini, Bowen juga mengenalkan konsep tidak adanya perbedaan ego keluarga. Konsep ini mengatakan bahwa ada keterkaitan dan kedekatan antara anggota keluarga yang membuat mereka saling mengerti dan memahami perasaan, khayalan, dan impian satu sama lain. Kedekatan ini dapat menyebabkan ketidaknyamanan yang pada akhirnya anggota keluarga memasuki fase saling menolak. Atas desakan kematangan dan aktualisasi diri, individu dituntut untuk memutuskan kelekatan emosi dengan keluarga asal mereka sehingga muncul perbedaan diri.

Kedua, Triangulasi. Menurut Bowel, hal dasar yang menghalangi sistem emosi keluarga adalah triangulasi atau melibatkan orang ketiga. Pada saat dua anggota dalam kondisi cemas, tertekan dan stres, mereka cenderung melibatkan orang ketiga untuk mengurangi intensitas stres dan memperoleh stabilitas. Keterlibatan orang ketiga dapat memberikan dampak positif dan negatif. Berdampak positif jika orang ketiga bersikap netral atau tidak memihak ke manapun atau menjadi penengah. Namun akan berdampak negatif jika orang 
ketiga berpihak kepada salah satu anggota keluarganya. Ketiga, Sistem emosional keluarga kecil. Setiap keluarga memiliki sistem emosional yang berbeda dan memiliki cara yang berbeda pula untuk mengurangi ketegangan emosi dan memelihara stabilitas emosi. Pada keluarga yang menghadapi kecemasan kronis dan ketidakstabilan emosi, maka cenderung mengembangkan jarak emosi satu sama lain yang mengakibatkan tidak berfungsinya aspek fisik dan emosi dalam interaksi keluarga. Apabila hal ini terus berlanjut, maka akan terjadi konflik dalam keluarga yang dapat memperburuk kondisi psikologis anak.

Keempat, Proses proyeksi keluarga. Proses proyeksi keluarga adalah proses emosional yang dijalani secara turuntemurun. Orang tua akan melekatkan emosinya kepada anak-anaknya. Anakanaknya akan melekatkan emosinya pada anak-anak mereka kelak, dan seterusnya. Individu yang tidak terlibat terlalu banyak dalam proyeksi keluarganya biasanya akan memiliki kemampuan yang baik dalam menahan pengaruh emosi orang lain dan akan mampu memisahkan antara emosi dan pikiran. Meski demikian, proyeksi keluarga ini tidak selalu bermakna negatif. Pada keluarga yang harmonis, proses emosional yang diturunkan juga akan memberikan dampak yang baik pada anak.

Kelima, Pemutusan emosi. Pemutusan emosi adalah pemisahan antara emosi diri dan keluarga. Dalam hal ini Bowen menuntut agar orang dewasa dapat memutuskan keterikatan emosinya dengan keluarga. Keenam, Posisi saudara kandung. Bowen mengatakan bahwa ada hubungan antara urutan kelahiran dan kepribadian seseorang. Pola interaksi suami istri sangat dipengaruhi oleh urutan kelahiran mereka. Misalnya, suami yang anak pertama dan istri yang anak terakhir (bungsu) cenderung membentuk pola hubungan suami yang dominan dan mengambil tanggung jawab dalam keluarga (Lubis, 2011).
Selanjutnya pendekatan model komunikasi. Komunikasi berupa verbal maupun nonverbal yang meliputi gesture, bahasa tubuh, nada suara, postur tubuh, dan intensitas perilaku. Komunikasi dalam keluarga ini dapat berfungsi untuk mengendalikan anggota keluarga, menegaskan kekuatan hubungan dan perintah, serta memfungsikan anggota keluarga menjadi lebih baik (Lubis, 2011).

Terakhir, pendekatan struktural. Konsep teori yang dituangkan Minuchin adalah bahwa keluarga merupakan suatu sistem sosial yang mengembangkan pola transaksi yang mengatur bagaimana, kapan dan kepada siapa anggota keluarga saling berhubungan. Artinya adalah sistem keluarga dibentuk oleh pola transaksional. Terdapat tiga istilah dalam pendekatan struktural yaitu subsistem, boundaries, dan alignment (Lubis, 2011).

\section{Konseling untuk Ketahanan Keluarga}

Konseling keluarga, seperti dipaparkan sebelumnya, lebih banyak berfokus pada penyelesaian persoalan pribadi yang bisa membawa dampak pada keluarga, terutama dengan melibatkan keberadaan keluarga itu sendiri. Dalam hal ini, perlu disadari bahwa berbagai persoalan atau problematika yang timbul dalam keluarga, seperti konflik antar anggota keluarga, perceraian, permusuhan saudara, kekerasan dalam rumah tangga, dan lainnya, seringkali bersumber dari persoalan-persoalan pribadi anggota keluarga yang tidak terselesaikan dengan baik. Persoalan-persoalan tersebut pada gilirannya juga dapat menimbulkan tekanan psikologis tertentu, seperti depresi, kecemasan, ataupun perilaku-perilaku maladaptif (kekerasan, perilaku agresif, dan lainnya) (Kolak dkk., 2018; D'Onofrio \& Emery, 2019).

Pentingnya konseling adalah untuk membantu anggota keluarga agar bisa menyikapi persoalan yang ada secara baik, lalu menemukan solusi yang tepat, seraya pada gilirannya mampu meningkatkan ketahanan keluarga itu sendiri. Persoalan 
dalam keluarga, jika bisa dikelola dengan baik, adalah anteseden untuk ketahanan keluarga. Semakin baik suatu keluarga dalam mengelola persoalan atau krisis yang ada, maka semakin baik pula ketahanan yang dimilikinya. Pada gilirannya, hal itu juga dapat berdampak pada kondisi kesehatan baik fisik ataupun mental anggota keluarga, serta kesejahteraan keluarga itu sendiri (Kelchner dkk., 2020).

Pada beberapa literatur yang disebutkan sebelumnya, keluarga pada dasarnya bisa dianggap sebagai sebuah sistem (Walsh, 2016; Ulfiah \& Hannah, 2018). Karena itu, ketahanan keluarga juga bisa dilihat sebagai suatu sistem yang memiliki input, proses, dan output. Pertama, Komponen input. Komponen ini meliputi sumber daya keluarga termasuk nilai dan tujuan yang menjadi dasar keluarga. Sumber daya keluarga memiliki makna sebagai sumber dari kekuatan, potensi dan kemampuan keluarga untuk mencapai suatu manfaat atau tujuan. Sumber daya keluarga merupakan apa yang dimiliki dan dikuasai individu dalam keluarga baik bersifat fisik-material maupun non fisik yang dapat diukur maupun tidak dapat diukur, sumber daya ekonomi manusia, maupun lingkungan di sekitar keluarga untuk mencapai tujuan keluarga itu sendiri. Contoh: keahlian yang dimiliki anggota keluarga, lingkungan yang memadai (lingkungan yang kondusif). Kedua, Komponen proses. Komponen ini merupakan proses keluarga mengelola sumber daya keluarga, masalah yang dihadapi dan penanggulangan masalah keluarga. Manajemen sumber daya keluarga merupakan pengelolaan keluarga atas sumber daya keluarga (baik yang dimiliki atau yang bisa diakses keluarga) seperti bagaimana mengelola waktu dalam keluarga, pembagian tugas dalam keluarga. Komponen proses merupakan bagaimana keluarga dapat mengatur masalah yang dihadapi sehingga tidak mengganggu kestabilan keluarga. Ketiga, Komponen output. Output dari ketahanan keluarga adalah kesejahteraan keluarga, yaitu terpenuhinya kebutuhan fisik dan nonfisik keluarga, kebutuhan dasar dan perkembangan keluarga (Ulfiah \& Hannah, 2018).

Memandang keluarga sebagai sebuah sistem ini berarti meyakini bahwa semua anggota keluarga memiliki hubungan dan keterikatan satu sama lain, yang tidak semata disebabkan kontrak sosial ataupun keturunan, tapi juga hubungan emosional, relasional, kultural, hingga spiritual. Kemampuan masing-masing anggota keluarga dalam merespon hubungan dan posisi mereka dalam sistem tersebut dapat memperkuat ketahanan keluarga itu sendiri. Hal ini sesuai dengan hasil beberapa studi yang menyebutkan bahwa beberapa atribut dasar dari ketahanan keluarga adalah keterhubungan satu sama lain (interconnectedness) (Oh \& Chang, 2014). Atribut lainnya, yang juga banyak muncul dalam literatur tentang ketahanan keluarga adalah kepercayaan diri kolektif, pandangan hidup positif, pola komunikasi terbuka, pemecahan masalah secara kolaboratif, dan keterpenuhan sumber daya. Semakin lengkap atribut ini pada suatu keluarga, maka semakin baik pula ketahanan keluarga bersangkutan (Oh \& Chang, 2014; Walsh, 2016).

Perlunya memandang keluarga sebagai sebuah sistem ini juga bisa dimaknai sebagai upaya untuk melihat ketahanan sebagai suatu hal yang tidak berdiri sendiri, melainkan terikat dan mendapatkan pengaruh dari berbagai hal, termasuk dari individu anggota keluarga ataupun lingkungan sosial. Dalam teorinya sendiri, berbagai model ketahanan keluarga, seperti model Hill's ABCX, model ketahanan McCubbin, model ABCX ganda, model FAAR, model T-Double ABCX, dan lainnya juga lebih banyak mempertimbangkan faktor-faktor interpersonal dan intra keluarga dibandingkan intrafisik. Dengan kata lain, terdapat perhatian yang lebih besar terhadap isu-isu sistemik, termasuk kecocokan antara anggota dan 
keluarga, atau antara keluarga dan komunitas. Pada titik ini juga, prinsipprinsip sosial yang menekankan bahwa individu selalu terikat dengan lingkungannya, lebih diperhatikan.

Pendekatan sistem seperti ini juga perlu ditekankan mengingat berbagai teori dan model ketahanan yang berkembang saat ini lebih banyak mengarah pada manfaat klinis. Hal ini berarti ketahanan keluarga perlu memerhatikan fungsi konseling dalam kaitannya dengan faktorfaktor holistik tersebut. Hal ini disebabkan adanya pertimbangan bahwa berbagai faktor ketahanan tidak berkaitan pada semata kondisi psikis individu dan tidak muncul pada masa-masa awal kehidupan berkeluarga, melainkan diuji seiring waktu yang dilalui. Karena itu, konseling lebih diperlukan terutama dalam mengembangkan sistem dukungan keluarga, atau memperbaiki pola komunikasi dan kohesi, dibandingkan pengembangan koherensi individu ataupun efikasi diri.

\section{Simpulan}

Berdasarkan hasil studi literatur yang ada, dapat dipahami bahwa pentingnya konseling keluarga adalah untuk membantu keluarga melewati situasi-situasi krisis dalam keluarga, menemukan solusi yang tepat, mengeluarkan potensi terbaik keluarga yang masih terpendam, mengembangkan kemampuan bekerjasama sebagai satu keluarga, ataupun berbagi peran dan tanggung jawab yang lebih adil. Karena itu, dalam berbagai teknik, metode, model, atau pendekatan konseling dalam keluarga, para terapis pada umumnya lebih berfokus pada upaya mendorong kehadiran keluarga dalam pemecahan masalah secara bersama-sama. Hal ini berarti suatu keluarga memerlukan pembagian peran dan fungsi keluarga yang baik, memastikan semua kebutuhan terpenuhi, atau menjalin komunikasi yang positif untuk penanganan persoalan secara lebih efektif. Pembagian peran dan fungsi dalam keluarga ini juga tidak otomatis menjadikan salah satu pihak lebih tinggi dibandingkan yang lain.

Ditemukan pula bahwa ketahanan keluarga dan konseling keluarga memiliki kaitan utilitas yang bisa membantu keluarga dalam menghadapi berbagai persoalan untuk meningkatkan ketahanannya. Meski demikian, perlu diperhatikan bentuk konseling keluarga yang tepat, termasuk teknik, model, dan pendekatan yang digunakan dalam konseling tersebut. Beberapa model dan teknik konseling menunjukkan bahwa ketepatan pemilihan konseling dan konteks klinis keluarga akan menentukan dampak dari konseling tersebut bagi ketahanan keluarga itu sendiri.

Secara lebih khusus, hasil riset sederhana ini juga menunjukkan bahwa berbagai bentuk terapi atau konseling untuk menangani problematika rumah tangga, memerlukan pertimbangan-pertimbangan seperti: (1) fleksibilitas terapi untuk beragam latar persoalan yang tidak sama antara satu keluarga dengan lainnya; (2) sifat humanistik dari terapi agar lebih mampu menyentuh sisi terdalam pasien dan tidak semata terpaku pada prosedur ilmiah yang ketat; (3) keadilan dalam memandang persoalan; dan (4) melibatkan pertimbangan konteks lokal-kultural yang secara sistemik berdampak pada keluarga dan ketahanan keluarga itu sendiri.

\section{Daftar Pustaka}

Afdal, A. (2015). Pemanfaatan konseling keluarga eksperensial untuk penyelesaian kasus kekerasan dalam rumah tangga. EDUCATIO Jurnal Pendidikan Indonesia, 1(1), 32-40. http://dx.doi.org/10.29210/1201528

Chew, J., \& Haase, A. M. (2016). Psychometric properties of the family resilience assessment scale: A Singaporean perspective. Epilepsy and Behavior, 61(1), 112-119. https://doi.org/10.1016/j.yebeh.2016.0 5.015 
Doho, Y. D. (2017). Etika berkomunikasi dalam mempertahankan keharmonisan berdasarkan periodisasi usia perkawinan (Studi fenomenologi pasangan suami istri di Keuskupan Agung Jakarta dan Keuskupan Bogor). Jurnal Ilmu Komunikasi dan Bisnis, 2(2), 66-87. http://dx.doi.org/10.36914/jikb.v2i2.24 5

D'Onofrio, B., \& Emery, R. (2019). Parental divorce or separation and children's mental health. World Psychiatry, 18(1), 100-101. https://doi.org/10.1002/wps.20590

Ennis, E., \& Bunting, B. P. (2013). Family burden, family health and personal mental health. BMC Public Health, 13(255), 1-9. https://doi.org/10.1186/1471-2458-13255

Evans, P., Turner, S., \& Trotter, C. (2012). The effectiveness of family and relationship therapy: A review of the literature. PACFA.

Froutan, R., Mazlom, R., Malekzadeh, Z., \& Mirhaghi, A. (2017). Relationship between resilience and personality traits in paramedics. International Journal of Emergency Services, 7, 111. http://dx.doi.org/10.1108/IJES-122016-0028

Gerung, F. B., \& Opit, H. C. (2020). Peran pastoral konseling kristen di tengah pandemi covid-19. POIMEN, Jurnal Pastoral Konseling, 1(1), 51-67. https://doi.org/10.51667/pjpk.v1i1.107

Gingerich, W. J., \& Eisengart, S. (2000). Solution-focused brief therapy: A review of the outcome research. Family Process, 39(4), 477-498. https://doi.org/10.1111/j.15455300.2000.39408.x

Gloria, C. T., \& Steinhardt, M. A. (2016). Relationships among positive emotions, coping, resilience and mental health positive emotions, resilience and health. Stress and Health: Journal of International
Society for the Investigation of Stress, 32(2), 145-156. https://doi.org/10.1002/smi.2589

Indrawati, E. S. (2015). Status sosial ekonomi dan intensitas komunikasi keluarga pada ibu rumah tangga di Panggung Kidul Semarang Utara. Jurnal Psikologi, 14(1), 52-57. https://doi.org/10.14710/jpu.14.1.52-57

Kelchner, V. P., Campbell, L. O., Howard, C. C., Bensinger, J., \& Lambie, G. W. (2020). The influence of school-based family counseling on elementary students and their families. The Family Journal: Counseling and Therapy for Couples and Families, 28(3), 273-282. https://doi.org/10.1177/106648072093 3537

Kolak, A. M., VanWade, C. L., \& Ross, L. T. (2018). Family unpredictability and psychological distress in early adulthood: The role of family closeness and coping mechanisms. Journal of Child and Family Studies, 27(12), 3842-3852. https://doi.org/10.1007/s10826-0181211-4

Komachi, M. H., \& Kamibeppu, K. (2018). Association between resilience, acute stress symptoms and characteristics of family members of patients at early admission to the intensive care unit. Mental Health and Prevention, 9, 3441.

https://doi.org/10.1016/j.mhp.2018.01. 001

Lehrl, S., Evangelou, M., \& Sammons, P. (2020). The home learning environment and its role in shaping children's educational development. School Effectiveness and School Improvement, An International Journal of Research, Policy and Practice, 31(1), $\quad$ 1-6. http://dx.doi.org/10.1080/09243453.20 20.1693487

Lubis, N. L. (2011). Memahami dasardasar konseling: Dalam teori dan 
praktik. Kencana Prenada Media Group.

Marie, N., \& McClanahan, S. (2012). Family structure, parental practices and high school completion. American Sociological Review, 56(3), 309-320.

McCaffrey, R., Hayes, R. M., Cassell, A., Miller-Reyes, S., Donaldson, A., \& Ferrell, C. (2012). The effect of an educational programme on attitudes of nurses and medical residents towards the benefits of positive communication and collaboration. Journal of Advanced Nursing, $\quad$ 68(2), 293-301. https://doi.org/10.1111/j.13652648.2011.05736.x

Nemeth, D., \& Olivier, T. W. (2017). Innovative approaches to individual and community resilience, from theory to practice (hal. 35-58). Elsevier.

Oh, S., \& Chang, S. J. (2014). Concept analysis: Family resilience. Open Journal of Nursing, 4(13), 980-990. http://dx.doi.org/10.4236/ojn.2014.413 105

Rahayu, S. M. (2017, Agustus 4-6). Konseling keluarga dengan pendekatan behavioral: Strategi mewujudkan keharmonisan dalam keluarga. Proceeding Seminar dan Lokakarya Nasional Revitalisasi Laboratorium dan Jurnal Ilmiah dalam Implementasi Kurikulum Bimbingan dan Konseling Berbasis KKNI, (hal. 264-272). Malang Jawa Timur.

Rashid, M. H.-U., Rahman, M. A., Hasan, M. I., \& Rahman, M. M. (2020). Educational psychology impact on primary education: A review. Journal of Research in Humanities and Social Science, 8(12), 17-20.

Roberts, C., Cheng, A.-L., \& Hunter, J. (2017). Resilience in families of children with autism and sleep problems using mixed methods. Journal of Pediatric Nursing, 37, 2-9. http://dx.doi.org/10.1016/j.pedn.2017.0 8.030
Ryan, R., O'Farrelly, C., \& Ramchandani, P. (2017). Parenting and child mental health. London Journal of Primary Care, $\quad 9, \quad 1-9$. http://dx.doi.org/10.1080/17571472.20 17.1361630

Strotenbeker, I. A., Houwen, J., Lucassen, P. L. B. J., Stappers, H. W., Assendelft, W. J. J., van Dulmen, S., Olde Hartman, T. C., \& Das, E. (2018). Quantifying positive communication: Doctor's language and patient anxiety in primary care consultations. Patient Education and Counseling, 101(9), 1577-1584.

https://doi.org/10.1016/j.pec.2018.05.0 02

Taylor, S. D., \& Distelberg, B. (2016). Predicting behavioral health outcomes among low-income families: Testing a socioecological model of family resilience determinants. Journal of Child and Famly Studies, 25(9), 27972807. https://doi.org/10.1007/s10826016-0440-7

Theiss, J. A. (2018). Family communication and resilience. Journal of Applied Communication Research, 46(1), 10-13. https://doi.org/10.1080/00909882.2018 .1426706

Ulfiah, U. (2016). Psikologi keluarga: Pemahaman hakikat keluarga dan penanganan problematika rumah tangga. Ghalia Indonesia.

Ulfiah, U., \& Hannah, N. (2018). Prostitusi remaja dan ketahanan keluarga. Psikoislamedia, 3(2), 163-187. http://dx.doi.org/10.22373/psikoislame dia.v3i2.5630

Walsh, F. (2016). Family resilience: A developmental systems. European Journal of Developmental, 13(3), 313324.

https://doi.org/10.1080/17405629.2016 .1154035

Yang, B., Feldman, M. W., \& Li, S. (2021). The status of family resilience: Effect of sustainable livelihoods in rural 
China. Social Indicators Research, 153, 1041-1064. https://doi.org/10.1007/s11205-02002518-1

Yanti, N. (2020). Mewujudkan keharmonisan rumah tangga dengan menggunakan konseling keluarga. AlIttizaan, 3(1), 9-18. http://dx.doi.org/10.24014/0.8710152 